() 2020, The Authors. Published by FASS Inc. and Elsevier Inc. on behalf of the American Dairy Science Association ${ }^{\circledR}$. This is an open access article under the CC BY-NC-ND license (http://creativecommons.org/licenses/by-nc-nd/4.0/).

\title{
Responses to rumen-protected choline in transition cows do not depend on prepartum body condition
}

\author{
J. M. Bollatti, ${ }^{1}$ M. G. Zenobi, ${ }^{1}$ B. A. Barton, ${ }^{2}$ C. R. Staples, ${ }^{1} \oplus$ and J. E. P. Santos ${ }^{1 *} \oplus$ \\ ${ }^{1}$ Department of Animal Sciences, University of Florida, Gainesville 32611 \\ ${ }^{2}$ Balchem Corp., New Hampton, NY 10958
}

\section{ABSTRACT}

It is often suggested that the benefits of supplemental rumen-protected choline (RPC) might be greater in cows predisposed to fatty liver, such as those that are overconditioned; however, limited data support this suggestion. Therefore, the hypothesis of this study was that responses to supplementing RPC to transition dairy cows is not dependent on the degree of fatness prepartum. Objectives were to evaluate the effects of supplementing RPC to transition dairy cows according to body condition score (BCS) prepartum on production and metabolic responses. Data from 2 randomized block experiments that evaluated the effects of RPC supplementation during the transition period were combined. Within each experiment, cows were assigned randomly to receive $0(\mathrm{CTRL})$ or $12.9 \mathrm{~g} / \mathrm{d}$ choline ion in an RPC form (CHOL) daily top-dressed onto the diet from $21 \mathrm{~d}$ prepartum to $21 \mathrm{~d}$ postpartum. Body condition was evaluated twice prepartum before enrollment and the mean value was used as an explanatory variable for statistical analyses. Data were collected for the last $21 \mathrm{~d}$ of gestation and the first $105 \mathrm{~d}$ postpartum. The BCS (mean \pm standard deviation) prepartum were $3.51 \pm 0.29$ and $3.51 \pm 0.32$ for CTRL and CHOL, respectively, and ranged from 2.69 to 4.25 . A total of 215 cows were enrolled in the respective experiments and contributed data for the incidence of diseases, whereas 192 cows contributed data for analyses of production responses, plasma metabolites, and liver composition. Irrespective of BCS, supplementing transition diets with CHOL increased yields of milk by $1.8 \mathrm{~kg} / \mathrm{d}$, fat by $0.08 \mathrm{~kg} / \mathrm{d}$, lactose by $0.08 \mathrm{~kg} / \mathrm{d}$, true protein by 0.04 $\mathrm{kg} / \mathrm{d}$, energy-corrected milk (ECM) by $1.9 \mathrm{~kg} / \mathrm{d}$, and fat-corrected milk by $2.1 \mathrm{~kg} / \mathrm{d}$. The improvements in productive performance were not followed by increased dry matter intake or measures of lipomobilization. Therefore, CHOL cows were more efficient in convert-

Received July 20, 2019.

Accepted November 3, 2019.

*Corresponding author: jepsantos@ufl.edu ing dry matter intake into ECM. Feeding CHOL increased concentration of hepatic triacylglycerol (CTRL $=3.23$ vs. $\mathrm{CHOL}=3.87 \%$ wet basis) in the first 21 d postpartum. Overconditioned cows were more prone to having exacerbated lipomobilization and increased prevalence and incidence of fatty liver, but no interactions between treatment and BCS were observed for body weight, BCS, or concentrations of metabolites in plasma or hepatic triacylglycerol. Treatment did not affect incidence of clinical diseases. Opposite to common suggestions, cows with increased hepatic triacylglycerol content also had increased yields of milk and ECM in the first $105 \mathrm{~d}$ postpartum. Collectively, these findings indicate that the effects of RPC supplementation during the transition period are independent of the degree of fatness of dairy cows prepartum. The findings also suggest that the effects on productive performance are not necessarily mediated by improvements in markers of metabolic health or reductions in hepatic triacylglycerol.

Key words: body condition, choline, dairy cow, transition

\section{INTRODUCTION}

Body condition score is a useful management tool to assess the degree of fatness of dairy cows (Otto et al., 1991). Cows with greater BCS prepartum typically experience increased losses of condition postpartum because they have less DMI in the first weeks of lactation (Stockdale, 2001). Nutrient intake affects energy balance, which influences the rate of lipolysis and tissue mobilization and, consequently, increases the influx of fatty acids into circulation and hepatic fat infiltration (Reid et al., 1986). Therefore, obesity has been suggested as the primary nutritional risk factor for fatty liver in dairy cows (Bobe et al., 2004).

One of the consequences of extensive lipolysis in late gestation and early lactation is increased triacylglycerol infiltration into the hepatic parenchyma (Rukkwamsuk et al., 1998), which is known to be negatively associated with postpartum health and performance (Bobe 
et al., 2004). Cows are susceptible to fatty liver in part because they have limited rate of hepatic lipoprotein secretion to export accumulated triacylglycerols (Emery et al., 1992). One of limiting factors for very-low density lipoprotein secretion is availability of phospholipids, in particular choline deficiency has been shown to result in hepatic steatosis in multiple mammalian models (Cole et al., 2012). In fact, supplementation with choline has been suggested to transition dairy cows because of its lipotropic effects (Erdman et al., 1984). Therefore, it is not uncommon to suggest that the benefits of supplemental choline might be greater in cows more predisposed to fatty liver, such as those that are overconditioned (Zahra et al., 2006).

Guretzky et al. (2006) supplemented diets of transition dairy cows with rumen-protected choline (RPC) at $12.9 \mathrm{~g} / \mathrm{d}$ of choline ion starting $3 \mathrm{wk}$ prepartum to 49 d postpartum. The authors observed that supplementation with RPC did not improve lactation performance or reduce hepatic triacylglycerol content. These cows had a mean BCS of 3.30 and lost 0.5 units in the first 3 wk postpartum and the authors suggested that the moderate BCS at the start of the experiment and the limited loss in early lactation likely limited the benefits of choline. Zahra et al. (2006) supplemented 182 cows either 0 or $12 \mathrm{~g} / \mathrm{d}$ of choline ion as RPC from $21 \mathrm{~d}$ prepartum to $28 \mathrm{~d}$ postpartum. Results indicated an interaction between RPC and BCS at the beginning of the experiment and responses to choline were observed in cows with BCS of at least 4.00. Although some have suggested that the benefits of choline might be present primarily in cows at greater risk of fatty liver, others have shown greater milk yield in cows supplemented with RPC even when prepartum BCS was moderate, around 3.00 (Amrutkar et al., 2015). Indeed, supplementation with RPC tended to increase yields of fat and $3.5 \%$ FCM in cows starting the experiment prepartum with BCS of 3.50 without a reduction in hepatic triacylglycerol (Piepenbrink and Overton, 2003). Therefore, the benefits of RPC on improving postpartum performance might not necessarily be associated with overconditioned cows prepartum or with reductions in fatty liver.

The hypothesis of the present study was that response to supplementing RPC to transition dairy cows is not dependent on the degree of fatness prepartum. Thus, the objectives of this study were to evaluate the effects of supplementing RPC to transition dairy cows according to BCS prepartum on production and metabolic responses. For that, data from 2 previous experiments in which 215 Holstein cows were supplemented with either 0 or $12.9 \mathrm{~g} / \mathrm{d}$ of choline ion from $3 \mathrm{wk}$ prepartum to $3 \mathrm{wk}$ postpartum were combined and analyzed according to BCS at the beginning of supplementation.

\section{MATERIALS AND METHODS}

Data from 2 independent experiments conducted at the University of Florida were combined (Zenobi et al., 2018a; Bollatti et al., 2020a,b) into a single file for analyses. Details of cows, housing, diets, and general management are presented in the respective manuscripts. The rationale for using the 2 experiments is that they were conducted following the same administration of choline to cows from $21 \mathrm{~d}$ prepartum to $21 \mathrm{~d}$ postpartum.

Each experiment followed a randomized block design and a total of 215 pregnant parous Holstein cows were enrolled in both experiments. In experiment 1 (Zenobi et al., 2018a), 102 cows were assigned randomly to 1 of 4 treatments arranged as a $2 \times 2$ factorial. Treatments were 2 levels of dietary $\mathrm{NE}_{\mathrm{L}}$ prepartum, 1.40 or $1.63 \mathrm{Mcal} / \mathrm{kg}$, and within each level of dietary $\mathrm{NE}_{\mathrm{L}}$, cows were supplemented with either $0 \mathrm{~g} / \mathrm{d}$ choline ion (CTRL; $\mathrm{n}=50)$ or $12.9 \mathrm{~g} / \mathrm{d}$ of choline ion from $21 \mathrm{~d}$ prepartum to $21 \mathrm{~d}$ postpartum $(\mathbf{C H O L} ; \mathrm{n}=52)$. In experiment 2 (Bollatti et al., 2020a,b), 113 cows were assigned randomly to 1 of 4 treatments arranged as a $2 \times$ 2 factorial. Treatments were $0 \mathrm{~g} / \mathrm{d}$ choline ion (CTRL; $\mathrm{n}=55)$ or $12.9 \mathrm{~g} / \mathrm{d}$ of choline ion supplemented from $21 \mathrm{~d}$ prepartum to $21 \mathrm{~d}$ postpartum $(\mathrm{CHOL} ; \mathrm{n}=58$ ). Within each of the 2 treatments applied during the transition period, cows received either 0 or $12.9 \mathrm{~g} / \mathrm{d}$ of choline ion after the transition period, from 22 to $105 \mathrm{~d}$ postpartum. Therefore, a total of 105 parous Holstein cows received CTRL and 110 parous Holstein cows received CHOL for this study. In both experiments, cows fed CHOL were supplemented with RPC product fed at $60 \mathrm{~g} / \mathrm{d}$ that contained $28.8 \%$ choline chloride to supply supplemented cows a daily dose of $12.9 \mathrm{~g}$ of choline ion (ReaShure, Balchem Corp., New Hampton, NY). The RPC product was mixed with ground corn and dried molasses in a 30:56:14 ratio (as-is basis) and topdressed individually at $200 \mathrm{~g} / \mathrm{d}$ onto the diet concurrent with the morning feeding to supplemented cows. Cows assigned to CTRL (0 g/d of choline ion) received 200 $\mathrm{g} / \mathrm{d}$ of a top-dressing of ground corn and dried molasses in an 80:20 ratio.

Description of the ingredient composition of diets and chemical assays to analyze diets are provided in the respective manuscripts (Zenobi et al., 2018a; Bollatti et al., 2020a). Supplemental Table S1 (https:// doi.org/10.3168/jds.2019-17302) depicts a summary of the chemical composition of diets. In both experiments, pre- and postpartum diets contained a source of blood meal enriched with ruminally protected methionine and lysine to increase the supply of MP and metabolizable methionine and lysine. In experiment 1, 2 diets, equally distributed between CTRL and CHOL treatments, 
were formulated to contain $1.40 \mathrm{Mcal}$ of $\mathrm{NE}_{\mathrm{L}} / \mathrm{kg}$ of $\mathrm{DM}$ and Met at $2.30 \%$ of MP or $1.63 \mathrm{Mcal}$ of $\mathrm{NE}_{\mathrm{L}} / \mathrm{kg}$ of $\mathrm{DM}$ and Met at $2.40 \%$ of MP. After calving, cows were fed the same diet for the first $105 \mathrm{~d}$ postpartum, which contained $1.68 \mathrm{Mcal}$ of $\mathrm{NE}_{\mathrm{L}} / \mathrm{kg}$ of $\mathrm{DM}$ and Met at $2.30 \%$ of MP. In experiment 2, all cows were fed the same prepartum diet in the last $21 \mathrm{~d}$ of gestation and the same postpartum diet for the first $105 \mathrm{~d}$ postpartum. The prepartum diet contained $1.54 \mathrm{Mcal}$ of $\mathrm{NE}_{\mathrm{L}} / \mathrm{kg}$ of $\mathrm{DM}$ and Met at $2.10 \% \mathrm{MP}$, whereas the postpartum diet contained $1.66 \mathrm{Mcal}$ of $\mathrm{NE}_{\mathrm{L}} / \mathrm{kg}$ of $\mathrm{DM}$ and Met at $2.04 \%$ of MP.

\section{$B C S$ and $B W$}

In each experiment, cows were scored for body condition by 2 trained evaluators using a 1 to 5 scale with increments of 0.25 units as depicted in the Elanco BCS chart (Elanco Animal Health, 2009). In experiment 1, cows were scored for body condition at 49 and $28 \mathrm{~d}$ prepartum. In experiment 2, cows were scored at 28 and 21 d prepartum. The 2 values were averaged to result in a mean BCS prepartum at the beginning of treatment administration of 0 or $12.9 \mathrm{~g}$ of choline ion. After that, cows were scored for body condition at wk 1 (week of calving), 2, 4, 7, 10, and 15 postpartum. The change in BCS prepartum was calculated for each cow as the BCS in the week of calving minus the mean BCS before the beginning of treatments. During postpartum, changes in BCS were calculated as the BCS at wk 4 postpartum or wk 15 postpartum minus the BCS in the week of calving. During the postpartum period, after each milking, cows were weighed on a walk-through scale (AfiWeigh, S.A.E. Afikim, Israel) located on the exit lane of the milking parlor.

\section{Measurements of DMI}

Each cow was randomly assigned to an individual feeding gate (American Calan Inc., Northwood, NH). Intake was recorded daily after enrollment, and data for the last $21 \mathrm{~d}$ of gestation were analyzed. Intake measured before administration of treatments with RPC was used as covariate for statistical analysis of DMI. Immediately after calving, all postpartum cows were moved to another pen and housed together where they remained for the first $105 \mathrm{~d}$ postpartum and intake was measured daily.

\section{Measurements of Yields of Milk and Milk Components}

Cows were milked twice a day and yields of milk were recorded automatically (AfiFlo milk meters, S.A.E.
Afikim). Samples of milk were collected weekly until 105 d postpartum, from 2 sequential milkings, morning and night, for measurements of concentrations of fat, true protein, lactose, and somatic cells at the Southeast Milk Inc. laboratory (Belleview, FL). The SCC was transformed to SCS for statistical analysis according to the formula SCS $=\log _{10}(\mathrm{SCC} / 12.5) / \log _{10}(2)$. Milk yield and composition from each sampling were used to calculate the final concentrations of milk components for each week. Yields of milk corrected for $3.5 \%$ fat and for energy were calculated according to NRC (2001) as follows: $3.5 \% \mathrm{FCM}, \mathrm{kg} / \mathrm{d}=(0.4324 \times$ milk yield $)$ $+(16.218 \times$ milk fat yield $) ; \mathrm{ECM}, \mathrm{kg} / \mathrm{d}=[(0.3246$ $\times$ milk yield $)+(12.86 \times$ fat yield $)+(7.04 \times$ protein yield)].

\section{Calculations of Net Energy Balance}

Energy balance was calculated using daily caloric intake from DMI and the energy content of the diets according to NRC (2001) and using the $\mathrm{NE}_{\mathrm{L}}$ system. The needs for maintenance were calculated based on the metabolic $\mathrm{BW}\left(\mathrm{NE}_{\mathrm{M}}, \mathrm{Mcal} / \mathrm{d}=\mathrm{BW}^{0.75} \times 0.08\right)$. Calories required for gestation of prepartum cows were calculated based on the birth BW of calves and adjusted for day of gestation (NRC, 2001). The $\mathrm{NE}_{\mathrm{L}}$ required for milk synthesis was calculated according to yields of fat, protein, and lactose based on NRC (2001), as follows: $\{$ milk yield $\times[(0.0929 \times$ fat $\%)+(0.0563 \times$ protein $\%)$ $+(0.0395 \times$ lactose $\%)]\}$.

\section{Blood and Liver Sampling}

Blood collected on $\mathrm{d}-14,-7,0,7,14$, and 21 relative to parturition were assayed for concentrations of glucose, free fatty acids, and BHB. Blood collected on d 0,1 , and 3 postpartum were assayed for concentrations of total calcium (tCa). Liver samples were collected and assayed for concentrations of triacylglycerol on $\mathrm{d}$ 7, 14, and 21 postpartum. Details of laboratory assays are presented in Zenobi et al. (2018a) and Bollatti et al. (2020b).

\section{Characterization and Diagnosis of Health Problems}

Diseases recorded and analyzed included milk fever, retained placenta, metritis, displaced abomasum, mastitis, and respiratory problems in the first $21 \mathrm{~d}$ postpartum, except mastitis that was evaluated for the first 105 d postpartum. Details of diagnosis are described in Zenobi et al. (2018a) and Bollatti et al. (2020b). Morbidity included any of the above clinical diseases and cows with more than one clinical disease were classified as having multiple diseases. 
Urine was sampled on $\mathrm{d} 4,7,10$, and 12 postpartum, or on any day the cow was suspected of having ketosis. Samples were assayed for concentrations of ketones using strips (URS-1K, Teco Diagnostics, Anaheim, CA), and cows with moderate $(\sim 0.4 \mathrm{mM})$ or large $(>0.8$ $\mathrm{m} M$ ) concentrations of ketones in urine were considered to have clinical ketosis. Hyperketonemia was defined as plasma BHB concentrations $>1.20 \mathrm{~m} M$ at least once on d $0,7,14$ and 21 postpartum based on McArt et al. (2011). Incidence of subclinical hypocalcemia was based on at least one sample with plasma tCa $<2.0$ $\mathrm{m} M$ (Reinhardt et al., 2011) on d 0, 1, or 3 postpartum. Daily prevalence of subclinical hypocalcemia was evaluated in the first $3 \mathrm{~d}$ postpartum. Incidence of fatty liver was determined based on at least 1 sample of hepatic tissue with triacylglycerol content greater than $5 \%$ of wet tissue (Gaal et al., 1983) on d 7, 14, or 21 postpartum. Furthermore, the prevalence of fatty liver also was evaluated in weekly samples collected from 7 to 21 d postpartum.

Vaginal discharge was collected at $21 \pm 3 \mathrm{~d}$ postpartum using the Metricheck device (Kiwikit Ltd., Wales, New Zealand) and scored as described by Sheldon et al. (2006). Cows having a vaginal discharge score $>2$ were classified as having endometritis (Sheldon et al., 2006).

\section{Statistical Analyses}

Data were analyzed by the MIXED or GLIMMIX procedures of SAS (version 9.4, SAS/STAT, SAS Institute Inc., Cary, NC). Continuous data were tested for the distribution of the residuals using Shapiro-Wilk and homogeneity of variance by plotting residuals against predicted values after fitting the statistical models. Non-normally distributed data were subjected to BoxCox transformation according to the TRANSREG procedure of SAS (SAS/STAT, SAS Institute Inc.) to meet the assumptions of normality before analyses. If final models remained the same and significance of parameters and interpretation of the data did not change with transformation, then the analysis was carried out on the original scale of the data to avoid back transformation of standard error of the means.

The initial statistical model included the fixed effects of treatment (CTRL vs. CHOL), prepartum BCS as a linear covariate, experiment (1 vs. 2), calf category (singleton male, singleton female, or twin), and time (week or day relative to calving), and the interactions between treatment and prepartum BCS, treatment and time, and treatment and experiment, and the random effect of cow nested within treatment. A stepwise backward elimination was applied for nonsignificant interactions $(P>0.10)$ with removal of model parameters sequentially according to the largest $P$-value. Therefore, when no interaction was significant, the final model included the forced parameters of the fixed effects of treatment, prepartum BCS, experiment, calf category, and time, and the random effect of cow nested within treatment. In all statistical models, the Kenward-Roger method was used to calculate the approximate denominator degrees of freedom for the $F$-tests. The REPEATED statement was used for dependent variables measured over time with the same experimental unit. Cow nested within treatment was the error term for testing the effects of treatment, BCS prepartum, and the interaction between treatment and BCS prepartum. The covariance structure with the smallest Akaike's information criterion was selected for each variable analyzed.

To understand if differences in productive responses were mediated by changes in hepatic triacylglycerol content, the yields of milk and ECM also were analyzed with the final models as previously described, but including the fixed effects of the mean triacylglycerol content (d 7, 14, and 21) of each cow as a covariate and the interaction between treatment and hepatic triacylglycerol content. The objective was to determine if the degree of triacylglycerol infiltration in the liver was associated with lactation performance in cows fed CTRL or CHOL.

Binary responses such as the incidence of diseases were analyzed by logistic regression using the GLIMMIX procedure of SAS (SAS/STAT, SAS Institute Inc.). Dispersion of the data was assessed by the ratio of the generalized chi-squared statistic and its degrees of freedom. In almost all final analyses, the generalized $\chi^{2} / \mathrm{df}$ was between 0.95 and 1.10 , suggesting that the variability in the data was properly modeled and that only minor residual under- or overdispersion was present in any of the final models used. In a few cases, dispersion problems were observed, and a multiplicative dispersion parameter estimated from Pearson's statistic was added to the models. Predicted probabilities from the mixed models were computed as least squares means \pm standard error of the mean on the scale of the data with the ILINK function of SAS (SAS/STAT, SAS Institute Inc.). The initial statistical model included the fixed effects of treatment, prepartum BCS, experiment, calf category, and the interactions between treatment and prepartum BCS and treatment and experiment. The daily prevalence of fatty liver evaluated on $\mathrm{d} 7,14$, and 21 postpartum was analyzed as repeated measures with the model previously described, but also including the fixed effects of day and interactions between treatment and day and treatment and BCS and day, and the random effect of cow nested within treatment. Nonsignificant interactions $(P>0.10)$ were removed from the models by backward stepwise elimination as described previously. 


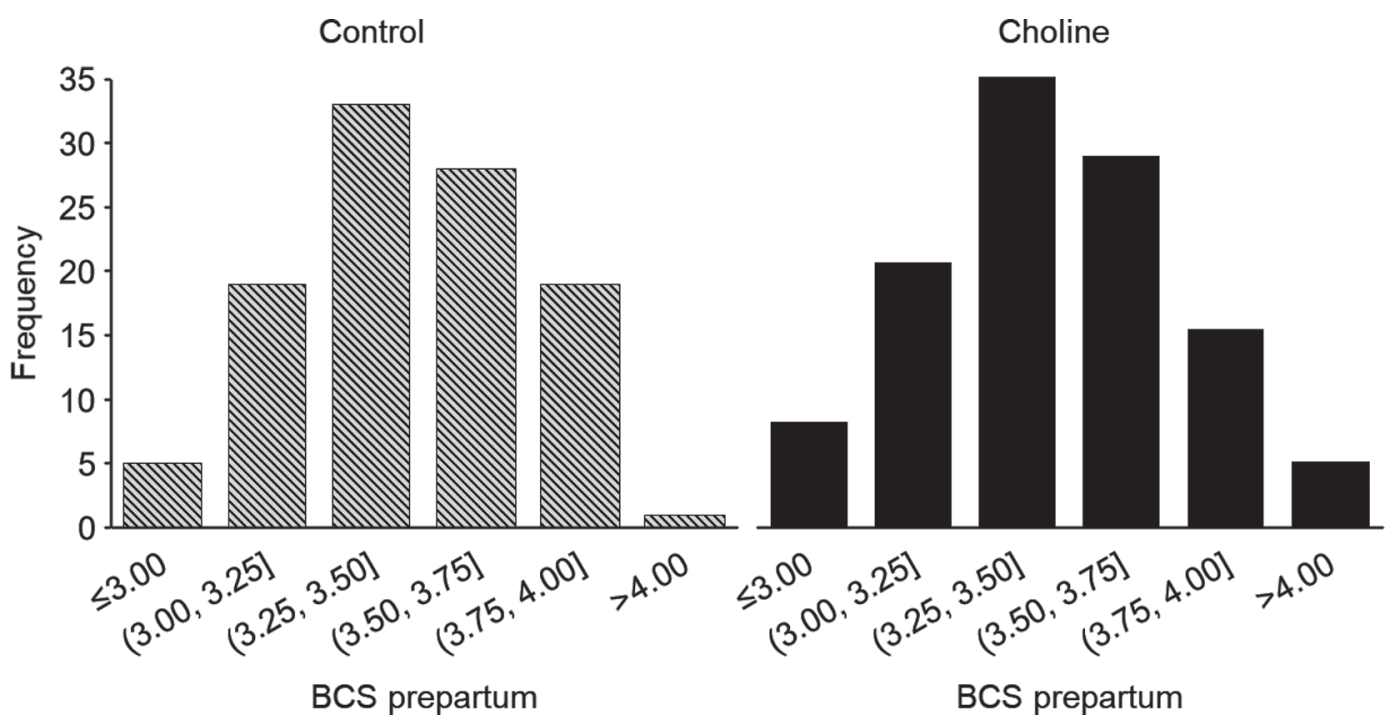

Figure 1. Distribution of dairy cows supplemented with either 0 (control) or $12.9 \mathrm{~g} / \mathrm{d}$ choline ion (choline) as rumen-protected choline according to BCS prepartum. Parentheses indicate an open interval that does not include the limit point, and brackets indicate a closed interval that does include the limit point.

Figures were generated with predicted responses for each cow contributing data for the analysis of the specific response according to treatment and prepartum BCS based on the random (best linear unbiased prediction) and fixed effects (best linear unbiased estimates) from the mixed models. Fitted lines for the effects of treatment according to BCS at enrollment were depicted when an effect $(P \leq 0.10)$ of treatment or interaction between treatment and BCS was observed. Fitted values with best linear unbiased estimates to supplementing choline (CTRL vs. CHOL) according to BCS prepartum of 3.25 (moderate) or 3.75 (overconditioned) were computed to present least squares means and respective standard error of the means. The rationale for the 2 selected categories was to obtain predicted values to supplemental RPC in cows with diverging $\mathrm{BCS}$ that are prevalent among the prepartum cows in the database of the present study and commonly found in the general population of prepartum cows.

Statistical significance was considered at $P \leq 0.05$ and tendency at $0.05<P \leq 0.10$.

\section{RESULTS}

A total of 215 cows were enrolled in the respective experiments and contributed data for the incidence of diseases in this study; however, 23 cows were not included in the analyses of production and metabolism because they were removed from the respective experiments for reasons described elsewhere (Zenobi et al., 2018a; Bollatti et al., 2020a). Therefore, 192 cows contributed data for statistical analyses of production responses, plasma metabolites, and liver composition.

Treatments were supplemented prepartum for an average of $18 \mathrm{~d}$. Details of descriptive statistics for cows in the study according to treatment are presented in Supplemental Table S2 (https://doi.org/10.3168/jds .2019-17302). Cows in both treatments had a mean BCS of 3.51 at enrollment. The distributions of BCS according to each treatment were similar and are depicted in Figure 1. The CTRL and CHOL treatments had, respectively, 24 and 25 cows with BCS equal to or less than 3.25, and 25 and 26 cows with BCS equal to or greater than 3.75 .

\section{DMI, Production Performance, and Energy Status}

Treatment did not interact $(P>0.10)$ with BCS of cows at enrollment for DMI pre- and postpartum, production performance, and energy status (Table 1). Dry matter intake was unaffected by treatment or prepartum BCS during the last 3 wk of gestation and the first 15 wk postpartum (Figures $2 \mathrm{~A}$ and $\mathrm{B}$ ); however, an increase in prepartum BCS was associated $(P<$ 0.001 ) with a reduced postpartum DMI as percentage of BW (Table 1). Supplementing diets with RPC in the transition period increased $(P<0.05)$ yields of milk by $1.8 \mathrm{~kg} / \mathrm{d}$ (Figure 2C), ECM by $1.9 \mathrm{~kg} / \mathrm{d}$ (Figure 2D), $3.5 \%$ FCM by $2.1 \mathrm{~kg} / \mathrm{d}$, fat by $0.08 \mathrm{~kg} / \mathrm{d}$ (Figure $2 \mathrm{E})$, lactose by $0.08 \mathrm{~kg} / \mathrm{d}$, and tended $(P=0.08)$ to increased yield of true protein by $0.04 \mathrm{~kg} / \mathrm{d}$ (Figure $2 \mathrm{~F})$. The least squares means and standard error of the means for the observed effects of treatment on produc- 
Table 1. Predicted productive responses and energy status to supplemental choline in the transition period according to BCS prepartum

\begin{tabular}{|c|c|c|c|c|c|c|c|c|}
\hline \multirow[b]{3}{*}{ Item $^{1}$} & \multicolumn{4}{|c|}{ Treatment $^{2}$} & \multirow[b]{3}{*}{ SEM } & \multirow{2}{*}{\multicolumn{3}{|c|}{$P$-value ${ }^{3}$}} \\
\hline & \multicolumn{2}{|c|}{ CTRL } & \multicolumn{2}{|c|}{ CHOL } & & & & \\
\hline & 3.25 & 3.75 & 3.25 & 3.75 & & TRT & $\mathrm{BCS}$ & $\mathrm{TRT} \times \mathrm{BCS}$ \\
\hline \multirow{2}{*}{\multicolumn{9}{|c|}{ Postpartum DMI }} \\
\hline & & & & & & & & \\
\hline $\mathrm{kg} / \mathrm{d}$ & 22.7 & 22.4 & 22.9 & 22.6 & 0.4 & 0.56 & 0.28 & 0.53 \\
\hline Milk & 42.3 & 43.8 & 44.1 & 45.5 & 1.0 & 0.04 & 0.05 & 0.32 \\
\hline $\mathrm{ECM}$ & 42.8 & 44.6 & 44.7 & 46.5 & 1.0 & 0.02 & 0.02 & 0.39 \\
\hline $3.5 \% \mathrm{FCM}$ & 43.7 & 45.5 & 45.8 & 47.6 & 1.0 & 0.02 & 0.02 & 0.39 \\
\hline ECM:DMI, kg/kg & 1.89 & 2.08 & 1.98 & 2.16 & 0.05 & 0.03 & $<0.001$ & 0.66 \\
\hline \multicolumn{9}{|l|}{ Fat } \\
\hline$\%$ & 3.76 & 3.82 & 3.79 & 3.84 & 0.07 & 0.66 & 0.27 & 0.74 \\
\hline $\mathrm{kg} / \mathrm{d}$ & 1.56 & 1.64 & 1.64 & 1.72 & 0.04 & 0.02 & 0.01 & 0.44 \\
\hline $\mathrm{kg} / \mathrm{d}$ & 2.03 & 2.10 & 2.11 & 2.18 & 0.05 & 0.04 & 0.05 & 0.26 \\
\hline SCS & 2.02 & 2.28 & 1.90 & 2.17 & 0.35 & 0.70 & 0.29 & 0.57 \\
\hline \multicolumn{9}{|l|}{ Net energy balance, Mcal/d } \\
\hline Prepartum & 1.17 & 1.41 & 0.97 & 1.21 & 0.44 & 0.59 & 0.46 & 0.12 \\
\hline Postpartum & -2.02 & -3.97 & -3.03 & -4.98 & 0.61 & 0.05 & $<0.001$ & 0.43 \\
\hline \multicolumn{9}{|l|}{ BW postpartum } \\
\hline $\mathrm{kg}$ & 646.3 & 686.2 & 648.2 & 688.1 & 8.9 & 0.81 & $<0.001$ & 0.42 \\
\hline Change, $\mathrm{kg} / \mathrm{d}$ & -0.24 & -0.44 & -0.35 & -0.54 & 0.16 & 0.15 & 0.001 & 0.36 \\
\hline \multicolumn{9}{|l|}{ BCS, 1 to 5} \\
\hline Mean postpartum & 3.12 & 3.36 & 3.12 & 3.36 & 0.03 & 0.99 & $<0.001$ & 0.81 \\
\hline \multicolumn{9}{|l|}{ Change } \\
\hline $21 \mathrm{~d}$ prepartum to calving & 0.015 & -0.141 & 0.041 & -0.115 & 0.026 & 0.27 & $<0.001$ & 0.79 \\
\hline 21 d prepartum to wk 4 & -0.16 & -0.43 & -0.12 & -0.40 & 0.04 & 0.25 & $<0.001$ & 0.59 \\
\hline Wk 1 to 4 & -0.17 & -0.29 & -0.16 & -0.28 & 0.04 & 0.74 & $<0.001$ & 0.47 \\
\hline
\end{tabular}

${ }^{1}$ Prepartum $=$ measurements in the last $21 \mathrm{~d}$ of gestation. Postpartum $=$ measurements in the first $105 \mathrm{~d}$ postpartum.

${ }^{2} \mathrm{CTRL}=0 \mathrm{~g} / \mathrm{d}$ choline ion from $21 \mathrm{~d}$ prepartum to $21 \mathrm{~d}$ postpartum; CHOL $=12.9 \mathrm{~g} / \mathrm{d}$ choline ion as rumen-protected choline (ReaShure, 28.8\% choline chloride; Balchem Corp., New Hampton, NY) from 21 d prepartum to 21 d postpartum. Predicted responses to treatments according to BCS evaluated prepartum.

${ }^{3} \mathrm{TRT}=$ effect of treatment $(\mathrm{CTRL}$ vs. $\mathrm{CHOL}) ; \mathrm{BCS}=$ linear effect of BCS on d 21 prepartum; TRT $\times$ BCS $=$ interaction between TRT and BCS.

tive performance are depicted in Supplemental Table S3 (https://doi.org/10.3168/jds.2019-17302).

A positive association $(P<0.05)$ was observed for BCS prepartum and yields of milk (Figure 2C), ECM (Figure 2D), 3.5\% FCM, fat (Figure 2E), and lactose. An increment in 0.25 units of BCS prepartum increased milk by $0.72 \mathrm{~kg} / \mathrm{d}, \mathrm{ECM}$ by $0.90 \mathrm{~kg} / \mathrm{d}, 3.5 \% \mathrm{FCM}$ by $0.90 \mathrm{~kg} / \mathrm{d}$, fat by $0.04 \mathrm{~kg} / \mathrm{d}$, and lactose by $0.13 \mathrm{~kg} / \mathrm{d}$. No association was observed between BCS and yield of true protein (Figure 2F). Furthermore, feeding RPC or BCS prepartum did not influence the concentrations of fat, true protein, lactose or somatic cells in milk (Table $1)$.

Interestingly, the yields of milk and ECM increased $(P<0.02)$ as the mean hepatic triacylglycerol content in the first $21 \mathrm{~d}$ postpartum increased irrespective of treatment (Figure 3). For each percentage unit of in- crease in hepatic triacylglycerol content on a wet basis, yields of milk and ECM increased by 0.54 and 0.66 $\mathrm{kg} / \mathrm{d}$, respectively.

Supplementing RPC increased $(P=0.03)$ efficiency of feed utilization by $0.09 \mathrm{~kg}$ of ECM per $\mathrm{kg}$ of DMI (Supplemental Table S3). Similarly, cows with increased BCS prepartum had improved $(P<0.001)$ feed conversion into ECM because the increments in yields of milk and milk components were not accompanied by changes in DMI. Each 0.25 unit increase in BCS prepartum resulted in $0.09 \mathrm{~kg}$ more ECM per $\mathrm{kg}$ of DMI. Consequently, the $\mathrm{NE}_{\mathrm{L}}$ balance postpartum was more negative $(P \leq 0.05)$ in cows fed RPC and cows with increased BCS prepartum. Despite more negative $\mathrm{NE}_{\mathrm{L}}$ balance in cows fed RPC, treatment did not affect the mean BW or daily changes in BW postpartum, and the BCS or BCS changes in the pre- or postpartum pe- 

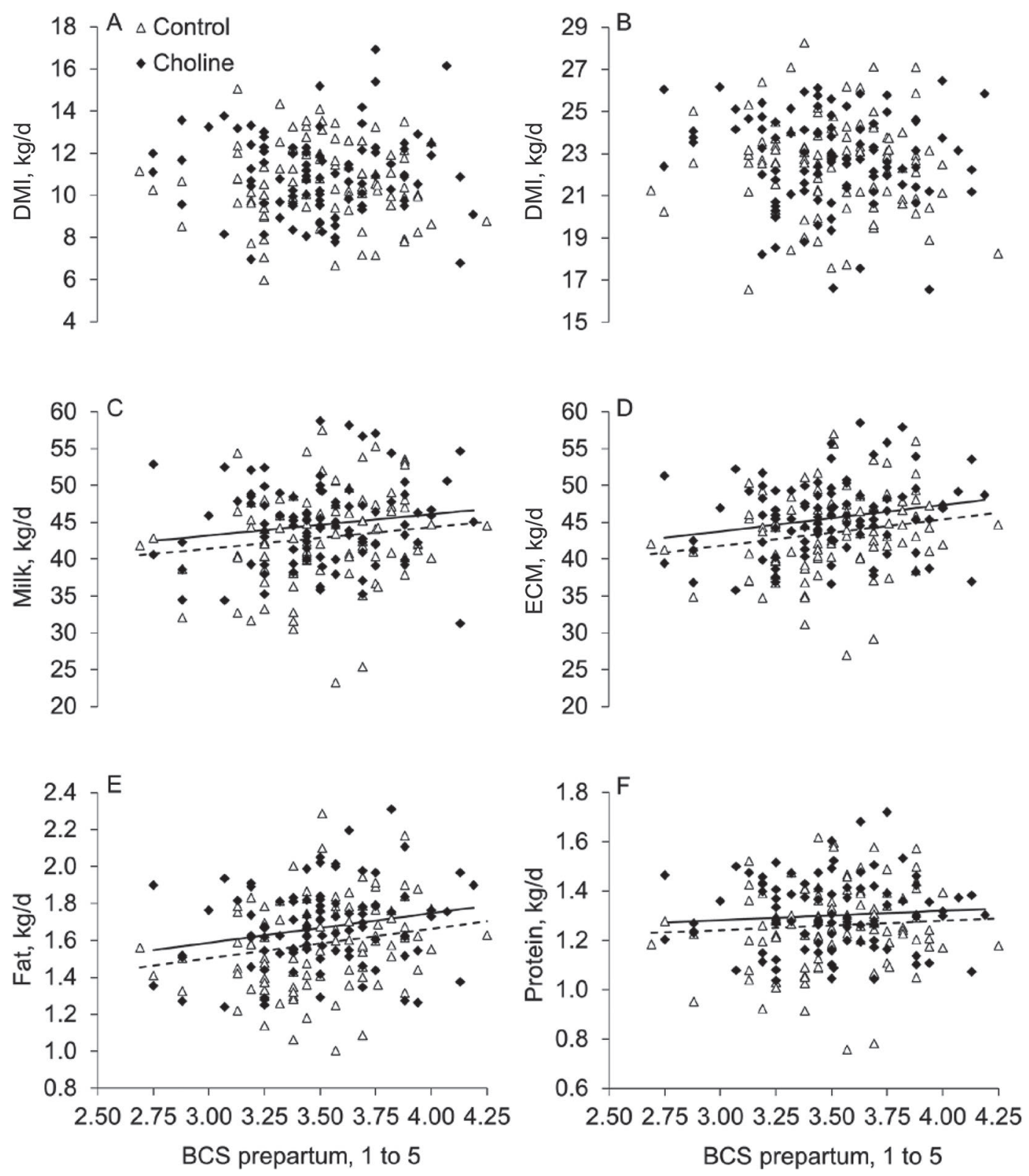

Figure 2. Dry matter intake in the last $21 \mathrm{~d}$ prepartum (A) and first $105 \mathrm{~d}$ postpartum (B), and yields of milk (C), ECM (D), fat (E), and true protein $(\mathrm{F})$ in the first $105 \mathrm{~d}$ postpartum in dairy cows supplemented with either 0 ( $\Delta$ and dashed line, control) or $12.9 \mathrm{~g} / \mathrm{d}$ choline ion $(\bullet$ and solid line, choline) as rumen-protected choline and according to the BCS prepartum. Lines for the response to treatments according to BCS are depicted when a statistical effect of treatment or interaction between treatment and BCS was detected. Panel A: effects of treatment $(P=$ 0.99), BCS $(P=0.14)$, and interaction between treatment and BCS $(P=0.11)$. Panel B: effects of treatment $(P=0.56)$, BCS $(P=0.28)$, and interaction between treatment and BCS $(P=0.53)$. Panel C: effects of treatment $(P=0.04)$, BCS $(P=0.05)$, and interaction between treatment and BCS $(P=0.32)$. Panel D: effects of treatment $(P=0.02)$, BCS $(P=0.02)$, and interaction between treatment and BCS $(P=0.39)$. Panel E: effects of treatment $(P=0.02)$, BCS $(P=0.01)$, and interaction between treatment and BCS $(P=0.44)$. Panel F: effects of treatment $(P=0.08)$, BCS $(P=0.33)$, and interaction between treatment and BCS $(P=0.29)$.

riods (Table 1). As BCS prepartum increased, the loss of BCS also increased $(P<0.001)$ during the last 21 $\mathrm{d}$ of gestation or the first $15 \mathrm{wk}$ of lactation (Table 1 ). Nevertheless, overconditioned cows prepartum still had greater $(P<0.001)$ mean $\mathrm{BW}$ and BCS postpartum (Table 1).

\section{Blood and Liver Metabolites}

An interaction $(P=0.01)$ was observed between treatment and BCS prepartum for plasma concentrations of glucose in the last 2 wk of gestation (Table 2 ; Figure 4A) because concentrations of glucose in 

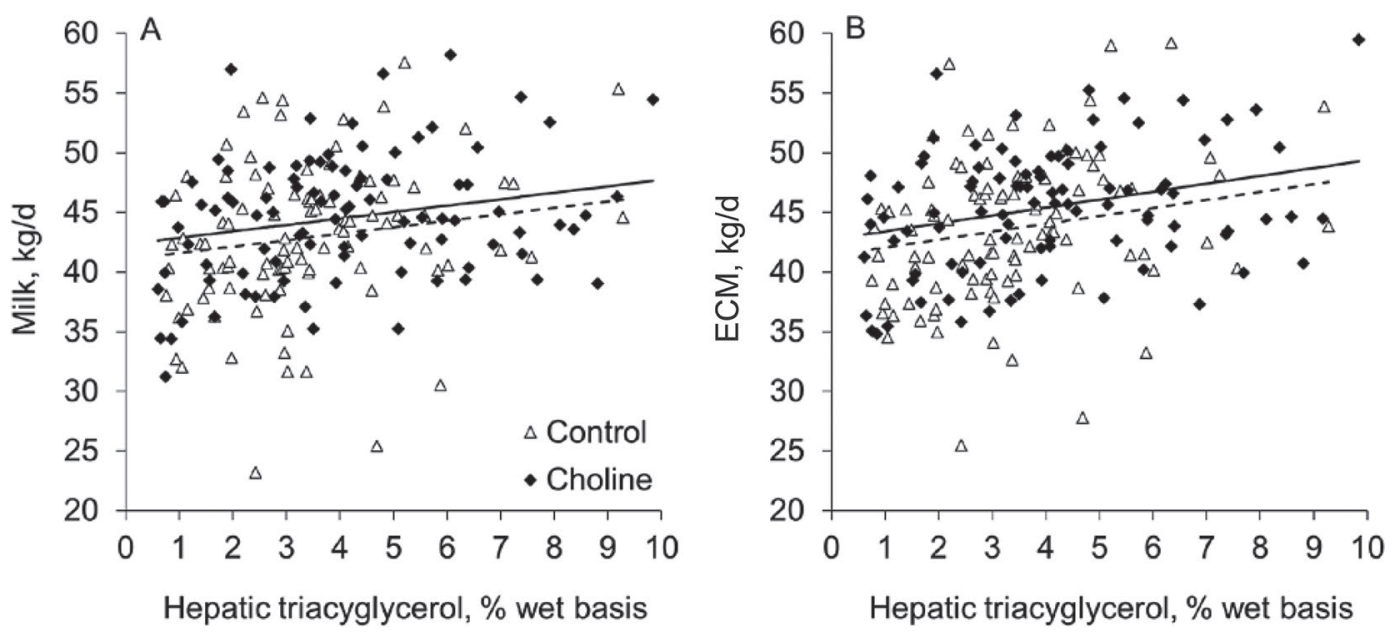

Figure 3. Yields of milk (A), and ECM (B) in the first $105 \mathrm{~d}$ postpartum in dairy cows supplemented with either $0(\Delta$ and dashed line, control) or $12.9 \mathrm{~g} / \mathrm{d}$ choline ion ( and solid line, choline) as rumen-protected choline and according to the mean postpartum hepatic triacylglycerol content. Lines for the response to treatments according to BCS are depicted when a statistical effect of treatment or interaction between treatment and BCS was detected. Panel A: effects of treatment $(P=0.04)$, hepatic triacylglycerol $(P=0.01)$, and interaction between treatment and hepatic triacylglycerol $(P=0.56)$. Panel B: effects of treatment $(P=0.02)$, hepatic triacylglycerol $(P=0.003)$, and interaction between treatment and hepatic triacylglycerol $(P=0.59)$.

CTRL increased as prepartum BCS increased, whereas in CHOL cows, concentrations of glucose decreased as prepartum BCS increased. Postpartum, concentrations of glucose in plasma were unaffected by treatment or by the BCS of cows prepartum (Figure 4B). No interactions were detected $(P>0.10)$ between treatment and prepartum BCS for the concentrations of fatty acids, BHB, or liver triacylglycerol. Supplementing RPC did not affect plasma concentrations of fatty acids or those of BHB, but it increased $(P<0.04)$ liver concentrations of triacylglycerol in the first $21 \mathrm{~d}$ postpartum by 1.5 percentage units on a DM basis (Figure 4D) or 0.64

Table 2. Predicted metabolic responses to supplemental choline in the transition period according to BCS prepartum

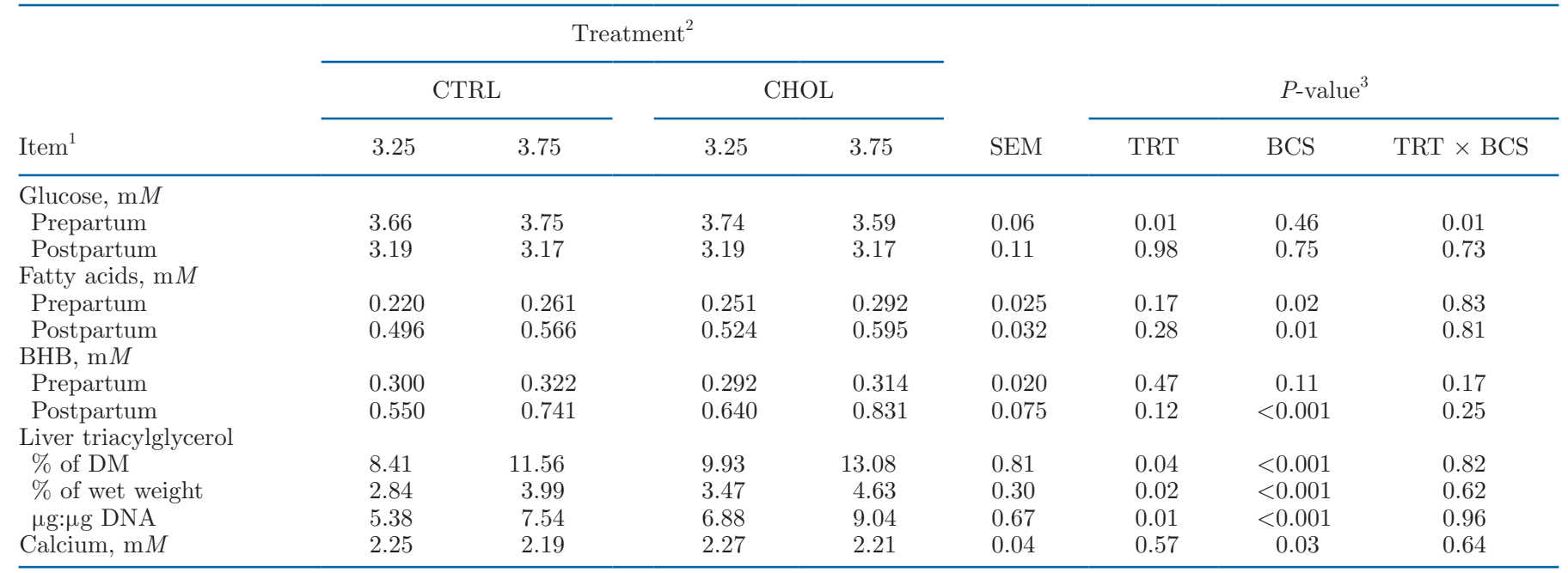

${ }^{1}$ Prepartum $=$ plasma analyzed on $\mathrm{d}-14$ and -7 relative calving; postpartum $=$ plasma analyzed on $\mathrm{d} 0,7,14$, and 21 ; liver triacylglycerol $=$ analyzed on d 7, 14, and 21 postpartum; calcium = plasma analyzed on d 0,1 , and 3 postpartum.

${ }^{2} \mathrm{CTRL}=0 \mathrm{~g} / \mathrm{d}$ choline ion from $21 \mathrm{~d}$ prepartum to $21 \mathrm{~d}$ postpartum; CHOL $=12.9 \mathrm{~g} / \mathrm{d}$ choline ion as rumen-protected choline (ReaShure, $28.8 \%$ choline chloride; Balchem Corp., New Hampton, NY) from $21 \mathrm{~d}$ prepartum to $21 \mathrm{~d}$ postpartum. Predicted responses to treatments according to BCS evaluated prepartum.

${ }^{3} \mathrm{TRT}=$ effect of treatment $(\mathrm{CTRL}$ vs. $\mathrm{CHOL}) ; \mathrm{BCS}=$ linear effect of BCS on d 21 prepartum; TRT $\times$ BCS $=$ interaction between $\mathrm{TRT}$ and BCS. 
percentage units on a wet basis (Supplemental Table S4; https://doi.org/10.3168/jds.2019-17302).

The body condition prepartum was associated with the concentrations of metabolites in circulation. As prepartum BCS increased, the concentrations of fatty acids also increased $(P<0.05)$ pre- and postpartum (Table 2; Figure 2C), and those of BHB increased $(P<$ 0.001) postpartum (Table 2). Similarly, as prepartum BCS increased, so did the concentrations of hepatic triacylglycerol postpartum (Table 2; Figure 2D). An increment in 0.25 units of prepartum BCS resulted in increases in $0.096 \mathrm{~m} M$ plasma BHB and 0.58 percentage units of triacylglycerol on wet basis.

Concentrations of tCa did not differ between treatments and no interaction between treatment and BCS prepartum was detected for plasma tCa (Table 2). As BCS prepartum increased, the concentration of tCa decreased $(P=0.03)$ in plasma.

\section{Postpartum Diseases}

Morbidity affected $43.8 \%$ of the cows in the study (Supplemental Table S5; https://doi.org/10.3168/jds .2019-17302). Milk fever and respiratory diseases were not reported in Table 3 because the low frequency of cases resulted in extreme underdispersion of data and poor predictability of the models. Five cases of milk fever were observed: $1 \mathrm{CTRL}$ and $4 \mathrm{CHOL}$, respectively. Of the 5 affected cows, 3 had BCS $<3.25$ and 2 had BCS $\geq 3.50$ prepartum. Respiratory disease affected 5 cows, 1 CTRL and 4 CHOL. Of those, 2 had a prepartum BCS $<3.25$ and 3 had a BCS $>3.50$. The cases of milk fever and respiratory disease contributed data for the analysis of morbidity and cows having multiple clinical diseases.

No interaction $(P>0.10)$ was observed between treatment and BCS prepartum for the incidence of
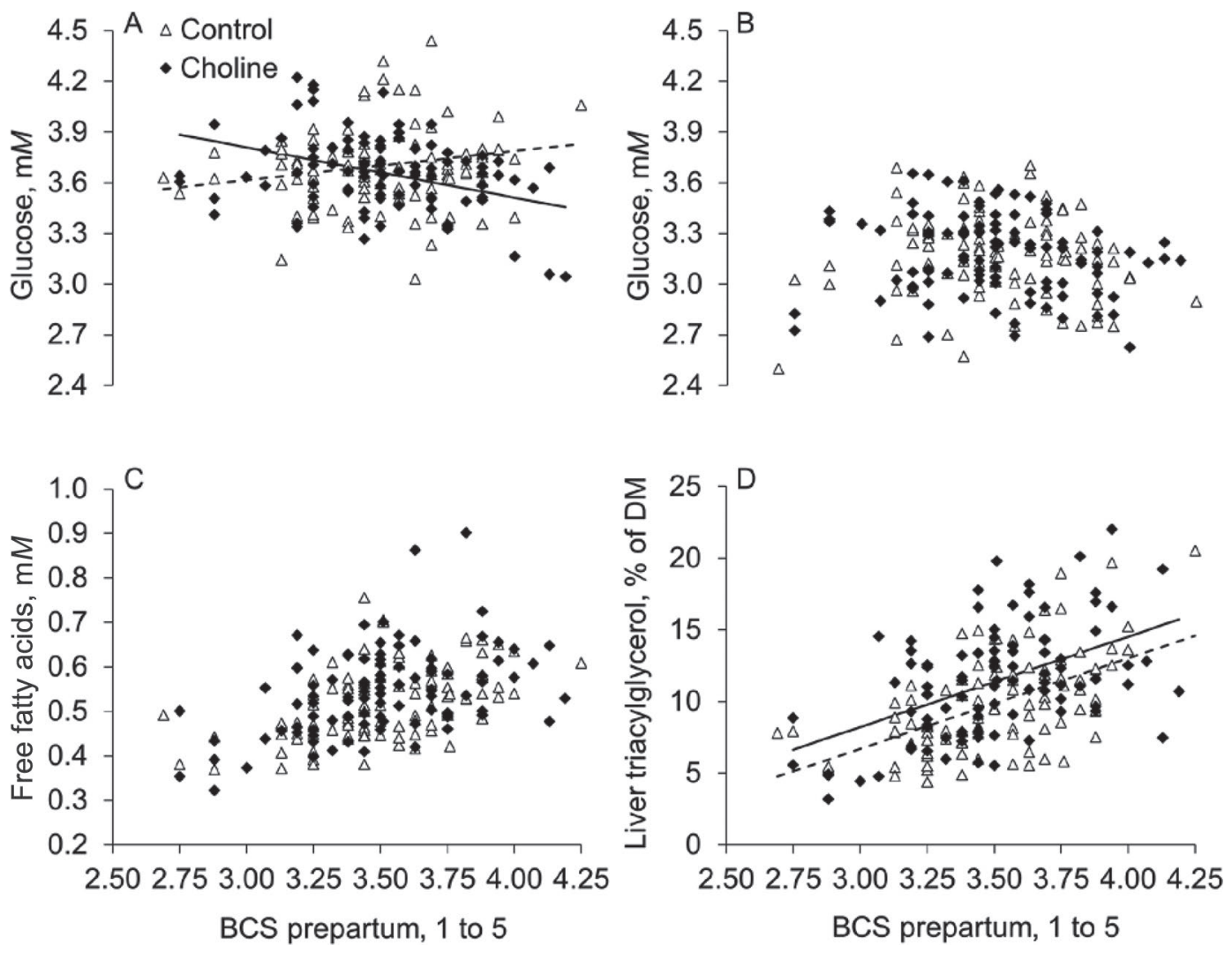

Figure 4. Concentrations of blood glucose prepartum (A) and postpartum (B), blood fatty acids postpartum (C), and liver triacylglycerol postpartum (D) in dairy cows supplemented with either 0 ( $\Delta$ and dashed line, control) or $12.9 \mathrm{~g} / \mathrm{d}$ choline ion ( $\bullet$ and solid line, choline) as rumen-protected choline and according to the BCS prepartum. Lines for the response to treatments according to BCS are depicted when a statistical effect of treatment or interaction between treatment and BCS was detected. Panel A: effects of treatment $(P=0.01)$, BCS $(P=0.46)$, and interaction between treatment and BCS $(P=0.01)$. Panel B: effects of treatment $(P=0.98)$, BCS $(P=0.75)$, and interaction between treatment and BCS $(P=0.73)$. Panel C: effects of treatment $(P=0.28)$, BCS $(P=0.01)$, and interaction between treatment and BCS $(P=$ $0.81)$. Panel D: effects of treatment $(P=0.04)$, BCS $(P<0.001)$, and interaction between treatment and BCS $(P=0.82)$. 
Table 3. Predicted incidence of clinical and subclinical diseases expressed as adjusted proportions according to treatment and BCS prepartum

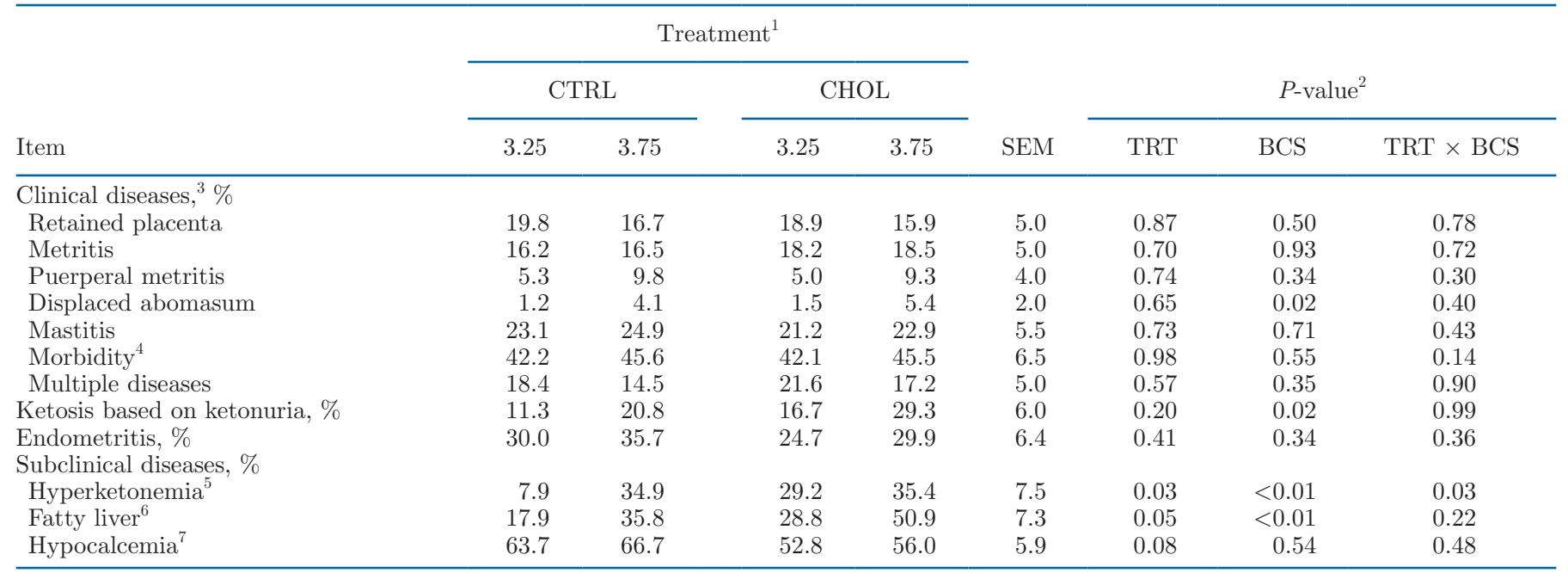

${ }^{1} \mathrm{CTRL}=0 \mathrm{~g} / \mathrm{d}$ choline ion from $21 \mathrm{~d}$ prepartum to $21 \mathrm{~d}$ postpartum; CHOL $=12.9 \mathrm{~g} / \mathrm{d}$ choline ion as rumen-protected choline (ReaShure, $28.8 \%$ choline chloride; Balchem Corp., New Hampton, NY) from $21 \mathrm{~d}$ prepartum to $21 \mathrm{~d}$ postpartum. Predicted responses to treatments according to BCS evaluated prepartum.

${ }^{2} \mathrm{TRT}=$ effect of treatment $(\mathrm{CTRL}$ vs. CHOL); BCS $=$ linear effect of BCS on d 21 prepartum; TRT $\times$ BCS $=$ interaction between TRT and BCS.

${ }^{3}$ Clinical diseases diagnosed in the first $21 \mathrm{~d}$ postpartum, except for mastitis that was diagnosed in the first $105 \mathrm{~d}$ postpartum.

${ }^{4}$ Morbidity included retained placenta, milk fever, metritis, displaced abomasum, respiratory problems, and mastitis.

${ }^{5} \mathrm{McArt}$ et al. (2011). Based on at least 1 plasma sample with BHB $>1.20 \mathrm{mM}$ on d 0, 7, 14, or 21 postpartum.

${ }^{6}$ Gaal et al. (1983). Based on at least 1 liver sample with triacylglycerol $>5 \%$ in wet basis on d 7, 14, or 21 postpartum.

${ }^{7}$ Reinhardt et al. (2011). Based on at least 1 plasma sample with tCa $<2.0 \mathrm{~m} M$ on d 0 , 1, or 3 postpartum.

individual clinical diseases, morbidity, and multiple clinical diseases (Table 3). Treatment with RPC did not affect the incidence of clinical diseases, morbidity, and multiple diseases. The risk of displaced abomasum increased $(P=0.02)$ as BCS prepartum increased (Table 3), but prepartum BCS was not associated with the incidence of other clinical diseases. Morbidity and incidence of multiple clinical diseases were not associated with prepartum BCS.

Treatment or the interaction between treatment and prepartum BCS did not affect the risk of ketosis or endometritis; however, the incidence of ketosis increased $(P=0.02)$ as prepartum BCS increased (Table 3$)$. An interaction $(P=0.03)$ between treatment and BCS was observed for incidence of hyperketonemia because CHOL cows had greater risk within those with low BCS, but the risk increased at a greater rate in CTRL than CHOL as BCS prepartum increased (Table 3). The incidence of fatty liver increased $(P=0.05)$ in the first 21 d postpartum in CHOL than CTRL, regardless of BCS; however, as BCS prepartum increased, so did the risk of fatty liver (Table 3$)$. Interestingly, an interaction $(P=$ 0.02 ) among treatment, BCS, and day postpartum was observed for the prevalence of fatty liver (Figure 5). Although cows fed CHOL always had greater prevalence of fatty liver than CTRL cows, the effect relative to
BCS was not consistent in the different days evaluated. On d 7 (Figure 5A) and 21 postpartum (Figure 5C), no interaction between treatment and BCS was observed for the prevalence of fatty liver. On the other hand, an interaction $(P=0.05)$ between treatment and BCS was detected on d 14 because cows fed CHOL had greater prevalence of fatty liver than CTRL cows in those with low to moderate BCS prepartum; however, in overconditioned cows, the prevalence of fatty liver did not differ between treatments. The incidence of subclinical hypocalcemia tended $(P=0.08)$ to be less for CHOL than CTRL (Supplemental Table S5; https://doi.org/ 10.3168/jds.2019-17302), and the effect was observed regardless of BCS.

\section{DISCUSSION}

Choline has well-demonstrated lipotropic effects in laboratory animals (Cole et al., 2012) and dairy cows (Cooke et al., 2007; Elek et al., 2013; Zenobi et al., 2018b), and overconditioned prepartum dairy cows have an increased risk of fatty liver (Bobe et al., 2004). Therefore, it is reasonable to suggest that potential effects of choline on improving lipid intermediary metabolism and lactation performance might be more easily observed in cows at an increased risk for hepatic lipido- 

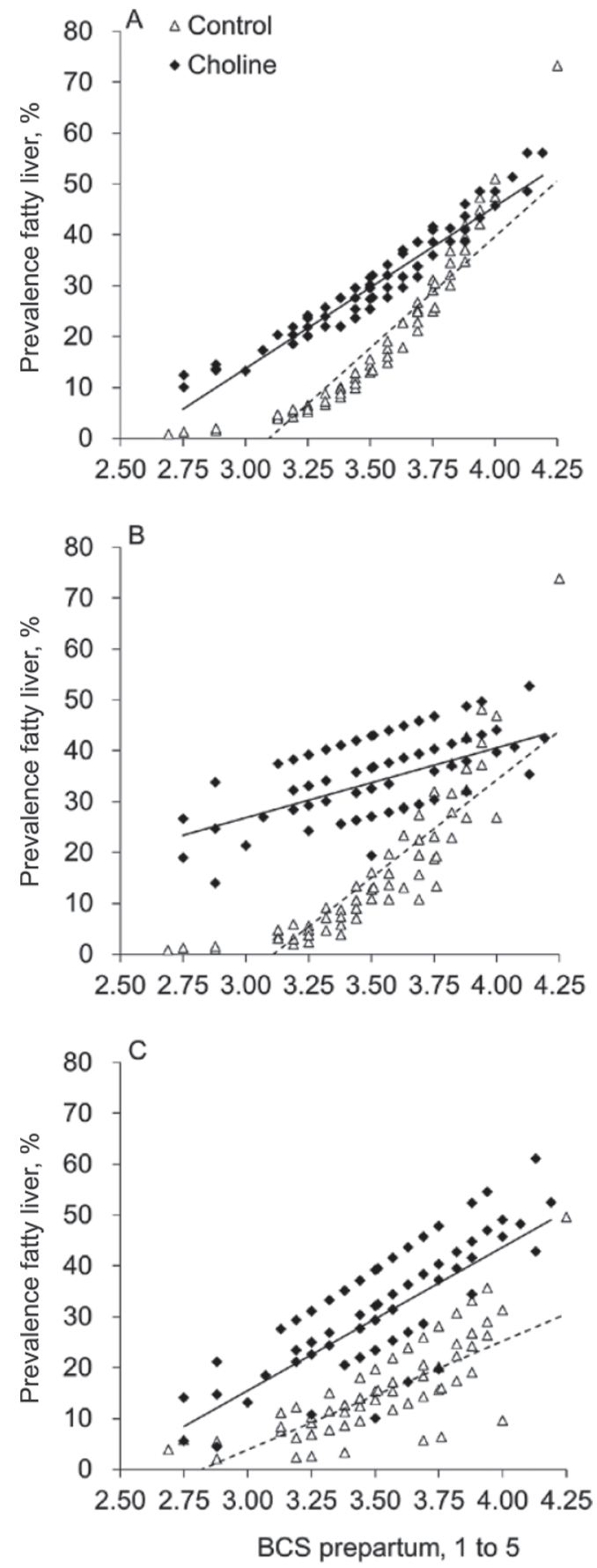

Figure 5. Prevalence of fatty liver on d 7 (A), 14 (B), and 21 postpartum $(\mathrm{C})$ in dairy cows supplemented with either 0 ( $\Delta$ and dashed line, control) or $12.9 \mathrm{~g} / \mathrm{d}$ choline ion $($ and solid line, choline) as rumen-protected choline and according to the BCS prepartum. Lines for the response to treatments according to BCS are depicted when a statistical effect of treatment or interaction between treatment and BCS was detected. An interaction $(P=0.02)$ among treatment, BCS, and day postpartum was detected, and data were partitioned to depict each day separately. Panel A: effects of treatment $(P=0.03)$, BCS $(P<0.001)$, and interaction between treatment and BCS $(P=$ $0.18)$. Panel B: effects of treatment $(P=0.03)$, BCS $(P=0.005)$, and interaction between treatment and BCS $(P=0.05)$. Panel C: effects of treatment $(P=0.01)$, BCS $(P=0.02)$, and interaction between treatment and $\mathrm{BCS}(P=0.75)$. sis, such as overconditioned cows (Zahra et al., 2006). Thus, we explored the effects of supplementing choline during the transition period on productive, metabolic, and health responses in dairy cows according to their prepartum BCS. The 2 experiments included in this study supplemented 0 or $12.9 \mathrm{~g} / \mathrm{d}$ choline ion from 21 d prepartum to $21 \mathrm{~d}$ postpartum and the 215 Holstein cows had BCS prepartum ranging from 2.69 to 4.25, providing a robust database to evaluate if responses to RPC are influenced by the degree of fatness of cows prepartum. Clearly, the results from this study showed that supplementing RPC improved yields of milk and milk components and increased efficiency of feed utilization in the first $105 \mathrm{~d}$ postpartum irrespective of $\mathrm{BCS}$, and the responses were not mediated by detectable improvements in metabolism or health.

The fact that choline supplementation increased yields of milk, fat, and protein, thus resulting in increased production of ECM during the first $105 \mathrm{~d}$ postpartum independent of the degree of fatness and the content of hepatic triacylglycerol seems to refute a common suggestion that improvements in lactation performance caused by choline are solely due to its role on reducing hepatic triacylglycerol content and preventing fatty liver. In fact, cows that produced more milk also had increased concentrations of triacylglycerol in the hepatic tissue in both CTRL and CHOL. Others have documented that supplementation with RPC during the transition period consistently increases yields of milk and ECM, but no differences were observed in the concentration of hepatic triacylglycerol (Arshad et al., 2020). The fact that production increased with supplemental choline in spite of prepartum BCS or a reduction in hepatic triacylglycerol or fatty liver points to potential mechanisms other than those related to hepatic lipid metabolism. Cows fed CHOL were more efficient in converting dietary DM into ECM and the increments in efficiency of feed utilization were not at the expense of body reserves because treatment did not affect the mean BW and BCS or the changes in BW or BCS postpartum. Indeed, concentrations of fatty acids or BHB in plasma postpartum did not differ between treatments, suggesting that improved production was not mediated by increased mobilization of body reserves.

Choline is known to be a structural component in cellular membranes and, also, to play a role in intermediary metabolism, in particular as a component of phospholipids and lipoproteins, which are critical for lipid absorption and transport. Choline biomolecules are in low concentrations during the peripartum period in dairy cows (Artegoitia et al., 2014). Deficiency of choline in lactating rats reduced the absorptive surface area in the intestine and resulted in an accumulation of 
lipids in part because of a small content of phosphatidylcholine in the intestine (da Silva et al., 2015), which impairs the secretion of chylomicron into lymph (Takahashi et al., 1982). In nonlactating dairy cows after feed restriction and subsequent fat challenge, RPC increased mean plasma concentration of triacylglycerol compared with nonsupplemented controls (Zenobi et al., 2018b), thereby suggesting that choline enhances the absorptive capacity of the gastrointestinal tract. Therefore, it is possible that nutrient absorption might be improved by choline, particularly lipids. In fact, Mohsen et al. (2011) observed that supplemental RPC increased coefficients of total-tract nutrient digestibility, which increased the calculated energy content of the diet and enhanced efficiency of yield of $4 \%$ FCM per unit of DMI. Moreover, it has been suggested that the decline in DMI around parturition may have detrimental effects on the gastrointestinal barrier (Kvidera et al., 2017). Changes in gut permeability could potentially facilitate the entry of antigens into the bloodstream and elicit an inflammatory response [i.e., induce an acute phase response (Kvidera et al., 2017)]. Zenobi et al. (2018b) subjected cows to feed restriction in an attempt to mimic the negative energy balance observed in early lactation. The authors observed that increasing the amount of RPC fed to feed-restricted cows linearly reduced the concentrations of haptoglobin in plasma (Zenobi et al., 2018b). It remains unknown if choline, its metabolites, or both have a direct effect on immune cells or if the effects are mediated by a potential constitutive role on gastrointestinal integrity, or a combination of both. In vitro, choline seems to have mixed effects stimulating or suppressing immune cells (Garcia et al., 2018). In vivo, supplementing choline to transition dairy cows reduced concentrations of pro-inflammatory cytokines (Sun et al., 2016) and reduced activation of in vitro stimulated immune cells (Zenobi et al., 2020). Therefore, it is possible that choline supplementation may enhance efficiency of feed conversion into ECM in part by reducing the flow of nutrients toward an activated immune system.

In this study, the incidence of clinical diseases and morbidity was unaffected by treatments. Therefore, the health benefits of choline may be more related to modulation of immune responses rather than preventing the incidence of infectious or metabolic diseases. Anti-inflammatory effects can be controversial because, on one hand, they can reduce the cost of maintaining surveillance against pathogens by activation of the immune system but, on the other hand, it might reduce immune cell responsiveness and not impede the establishment of disease (Mallard et al., 1998). Nevertheless, supplementing RPC has been shown to reduce the incidence of clinical ketosis, mastitis, and morbidity in transition cows when supplemented pre- and postpartum (Lima et al., 2012). Recently, Arshad et al. (2020) showed that supplementing diets of transition dairy cows with RPC tended to reduce the incidence of retained fetal membranes and mastitis. Therefore, the effects of supplementing diets of transition cows with RPC have not been consistent on its effects on risk of peripartum diseases and warrant further investigation. A reason for lack of consistency might be the nature of disease data that require properly powered experiments with hundreds of cows per treatment to be meaningful, a design that is rarely applied in dairy cattle nutrition.

The effects of RPC on lactation performance observed in this study were carried over at least $12 \mathrm{wk}$ after supplementation withdrawal, consistent with the results of each experiment used in the study (Zenobi et al., 2018a; Bollatti et al., 2020a). Also, carryover effects of RPC were observed regardless of the BCS prepartum. It is not uncommon for manipulations during the early postpartum period to extend its effects past the period of treatment implementation. For instance, Bar-Peled et al. (1995) demonstrated carryover effects on milk production by increasing milking frequency in early lactation, which may be due to increased mammogenesis with increased secretory capacity of the mammary gland (Capuco et al., 2003). It is possible that supplemental choline during early lactation may increase mammary growth by stimulating further the activity of choline kinase, which regulates mammary cell proliferation (Ramírez de Molina et al., 2004).

As BCS prepartum increased, ECM increased with no differences in DMI, which resulted in overconditioned cows having increased mobilization of body reserves, more negative $\mathrm{NE}_{\mathrm{L}}$ balance, and increased hepatic triacylglycerol content. In spite of the role of choline on hepatic lipid transport shown in laboratory animals (Cole et al., 2012) and reducing fatty liver in dairy cows (Cooke et al., 2007; Elek et al., 2013; Zenobi et al., 2018b), results from the present study demonstrate that RPC improved lactation performance at the same time that it did not reduce hepatic concentrations of triacylglycerol at any level of BCS. As previously suggested, the effect of choline on hepatic triacylglycerol was likely overshadowed by the enhanced productive performance of supplemented cows. Also, it is possible that the $12.9 \mathrm{~g} / \mathrm{d}$ dose of choline ion, the most commonly supplemented amount to transition cows (Arshad et al., 2020), may not be ideal to both stimulate milk yield and provide lipotropic effects in improving hepatic triacylglycerol export by the liver. Zenobi et al. (2018b) demonstrated that increasing the amounts of choline ion from 0 to $25.8 \mathrm{~g} / \mathrm{d}$ as RPC linearly reduced 
the concentration of hepatic triacylglycerol and plasma concentration of haptoglobin in nonlactating Holstein cows in negative $\mathrm{NE}_{\mathrm{L}}$ balance. Arshad et al. (2020) showed that increasing the amount of supplemental choline ion from 0 to $25.2 \mathrm{~g} / \mathrm{d}$ fed as RPC linearly increased yields of ECM and milk components. In lactating dairy cows, a large amount of choline is secreted in milk (Deuchler et al., 1998; Artegoitia et al., 2014); therefore, the daily amount of choline that combines improvements in lactation performance and reduction in fatty liver might be greater than that fed in the present study. In some experiments with transition cows, the combined improvements in lactation performance and reduced hepatic triacylglycerol with feeding 12.9 $\mathrm{g} / \mathrm{d}$ choline ion as RPC were accompanied by increased DMI postpartum (Santos and Lima, 2009; Zom et al., 2011). In others (Elek et al., 2008, 2013) in which RPC improved milk yield and reduced hepatic triacylglycerol content, cows were fed larger doses of choline ion, 18.8 and $37.5 \mathrm{~g} / \mathrm{d}$ pre- and postpartum, respectively. Therefore, it is possible that the lack of response in hepatic triacylglycerol to supplemental choline observed in the present study might have been caused by the improved lactation performance without a corresponding increase in DMI or by the dose of choline fed to cows. Perhaps, more than $12.9 \mathrm{~g} / \mathrm{d}$ might be needed to optimize lactation performance and liver health.

The threshold of hepatic triacylglycerol used to define cows with fatty liver was that suggested by Gaal et al. (1983) based on the original survey work by Reid (1980). Although the classification of hepatic triacylglycerol greater than $5 \%$ as indicator of fatty liver has been used by others (Jorritsma et al., 2000, 2001; Bobe et al., 2004), the threshold was not established based on accuracy to predict risk of clinical diseases, survival, or production. Nevertheless, epidemiological studies that used such threshold have established associations between fatty liver and reduced reproductive performance (Jorritsma et al., 2000). When cows are in a well-fed state, hepatic triacylglycerol represents less than 3\% of the tissue weight (Katoh, 2002; Fry et al., 2018), and increases in hepatic triacylglycerol above $5 \%$ of the tissue weight likely represent extensive lipomobilization, which is known to depress reproduction. The fact that hepatic triacylglycerol content was positively associated with milk yield in the present study and that by others (Jorritsma et al., 2001) poses the argument that increments in hepatic lipids might not necessarily be detrimental to performance. Thus, a more objective assessment of critical thresholds to classify fatty liver is needed and this assessment should be based on subsequent effects on health, survival, performance, and reproduction in dairy cows.

\section{CONCLUSIONS}

Supplementing choline ion as RPC to transition dairy cows improved production and feed efficiency regardless of prepartum degree of fatness. Although overconditioned cows were more prone to having exacerbated lipomobilization and increased prevalence and incidence of fatty liver, their response to choline in improving lactation performance was of similar magnitude to that observed in cows with low or moderated BCS. Nevertheless, the improvements in productive performance caused by choline were not mediated by reduced hepatic triacylglycerol or incidence of clinical diseases. Cows fed choline were more feed efficient without showing any indication of increased tissue mobilization, suggesting that supplementation with RPC either reduces nutrient needs for maintenance of early-lactation cows or improves nutrient absorption and transport for synthesis of milk components. Collectively, these findings support that the effects of RPC supplementation during the transition period are observed in cows of low and moderate BCS, as well as in overconditioned cows. The data also suggest that the effects on productive performance are not necessarily mediated by improvements in markers of metabolic health or reductions in hepatic triacylglycerol. Further research is warranted to understand the role of choline in improving nutrient utilization for milk synthesis beyond its role in liver function.

\section{ACKNOWLEDGMENTS}

This study was partially supported by a grant from Balchem Animal Nutrition and Health (New Hampton, NY). The authors have not stated any conflicts of interest. B. A. Barton is a retired employee of Balchem Animal Nutrition and Health.

\section{REFERENCES}

Amrutkar, S. A., S. P. Pawar, S. S. Thakur, N. J. Kewalramani, and M. S. Mahesh. 2015. Dietary supplementation of rumen-protected methionine, lysine and choline improves lactation performance and blood metabolic profile of Karan-Fries cows. Agric. Res. 4:396-404. https://doi.org/10.1007/s40003-015-0178-2.

Arshad, U., M. G. Zenobi, C. R. Staples, and J. E. P. Santos. 2020. Meta-analysis of the effects of supplemental rumen-protected choline during the transition period on performance and health of parous dairy cow. J. Dairy Sci. https://doi.org/10.3168/jds.2019 -16842 .

Artegoitia, V. M., J. L. Middleton, F. M. Harte, S. R. Campagna, and M. J. De Veth. 2014. Choline and choline metabolite patterns and associations in blood and milk during lactation in dairy cows. PLoS One 9:e103412. https://doi.org/10.1371/journal.pone .0103412 .

Bar-Peled, U., E. Maltz, I. Bruckental, Y. Folman, Y. Kali, H. Gacitua, A. R. Lehrer, C. H. Knight, B. Robinzon, H. Voet, and H. 
Tagari. 1995. Relationship between frequent milking or suckling in early lactation and milk production of high producing dairy cows. J. Dairy Sci. 78:2726-2736. https://doi.org/10.3168/jds.S0022 -0302(95)76903-X.

Bobe, G., J. W. Young, and D. C. Beitz. 2004. Invited review: Pathology, etiology, prevention, and treatment of fatty liver in dairy cows. J. Dairy Sci. 87:3105-3124. https://doi.org/10.3168/jds .S0022-0302(04)73446-3.

Bollatti, J. M., M. G. Zenobi, N. A. Artusso, G. F. Alfaro, A. M. Lopez, B. A. Barton, C. R. Staples, and J. E. P. Santos. 2020a. Timing of initiation and duration of feeding rumen-protected choline affects performance of lactating Holstein cows. J. Dairy Sci. 103. https://doi.org/10.3168/jds.2019-17293.

Bollatti, J. M., M. G. Zenobi, N. A. Artusso, A. M. Lopez, C. D. Nelson, B. A. Barton, C. R. Staples, and J. E. P. Santos. 2020b. Effects of rumen-protected choline on the inflammatory and metabolic status and health of dairy cows during the transition period. J. Dairy Sci. 103. https://doi.org/10.3168/jds.2019-17294.

Capuco, A. V., S. E. Ellis, S. A. Hale, E. Long, R. A. Erdman, X. Zhao, and M. J. Paape. 2003. Lactation persistency: Insights from mammary cell proliferation studies. J. Anim. Sci. 81(15_suppl_3):18-31. https://doi.org/10.2527/2003.81suppl_318x.

Cole, L. K., J. E. Vance, and D. E. Vance. 2012. Phosphatidylcholine biosynthesis and lipoprotein metabolism. Biochim. Biophys. Acta Mol. Cell Biol. Lipids 1821:754-761. https://doi.org/10.1016/j .bbalip.2011.09.009.

Cooke, R. F., N. S. Del Río, D. Z. Caraviello, S. J. Bertics, M. H. Ramos, and R. R. Grummer. 2007. Supplemental choline for prevention and alleviation of fatty liver in dairy cattle. J. Dairy Sci. 90:2413-2418. https://doi.org/10.3168/jds.2006-028.

da Silva, R. P., K. B. Kelly, E. D. Lewis, K. Leonard, S. Goruk, J. M. Curtis, D. F. Vine, S. D. Proctor, C. J. Field, and R. L. Jacobs. 2015. Choline deficiency impairs intestinal lipid metabolism in the lactating rat. J. Nutr. Biochem. 26:1077-1083. https://doi.org/10 .1016/j.jnutbio.2015.04.015.

Deuchler, K. N., L. S. Piperova, and R. A. Erdman. 1998. Milk choline secretion as an indirect indicator of postruminal choline supply. J. Dairy Sci. 81:238-242. https://doi.org/10.3168/jds.S0022 -0302(98)75571-7.

Elanco Animal Health. 2009. The 5-point body condition scoring system. Bulletin AI 10752. Elanco Animal Health, Greenfield, IN.

Elek, P., T. Gaál, and F. Husvéth. 2013. Influence of rumen-protected choline on liver composition and blood variables indicating energy balance in periparturient dairy cows. Acta Vet. Hung. 61:59-70. https://doi.org/10.1556/AVet.2012.053.

Elek, P., J. R. Newbold, T. Gaal, L. Wagner, and F. Husveth. 2008. Effects of rumen-protected choline supplementation on milk production and choline supply of periparturient dairy cows. Animal 2:1595-1601. https://doi.org/10.1017/S1751731108002917.

Emery, R. S., J. S. Liesman, and T. H. Herdt. 1992. Metabolism of long chain fatty acids by ruminant liver. J. Nutr. 122(suppl_3):832-837. https://doi.org/10.1093/jn/122.suppl_3.832.

Erdman, R. A., R. D. Shaver, and J. H. Vandersall. 1984. Dietary choline for the lactating cow: possible effects on milk fat synthesis. J. Dairy Sci. 67:410-415. https://doi.org/10.3168/jds.S0022 $-0302(84) 81317-\mathrm{X}$.

Fry, M. M., B. Yao, C. Ríos, C. Wong, S. Mann, J. A. A. McArt, D. V. Nydam, F. A. Leal Yepes, L. Viesselmann, A. Geick, K. Goldin, A. Jordan, and E. Behling-Kelly. 2018. Diagnostic performance of cytology for assessment of hepatic lipid content in dairy cattle. J. Dairy Sci. 101:1379-1387. https://doi.org/10.3168/jds.2017-12897.

Gaal, T., I. M. Reid, R. A. Collins, C. J. Roberts, and B. V. Pike. 1983. Comparison of biochemical and histological methods of estimating fat content of liver of dairy cows. Res. Vet. Sci. 34:245-248. https://doi.org/10.1016/S0034-5288(18)32268-9.

Garcia, M., L. K. Mamedova, B. Barton, and B. J. Bradford. 2018. Choline regulates the function of bovine immune cells and alters the mRNA abundance of enzymes and receptors involved in its metabolism in vitro. Front. Immunol. 9:2448. https://doi.org/10 .3389 /fimmu.2018.02448.
Guretzky, N. A. J., D. B. Carlson, J. E. Garrett, and J. K. Drackley. 2006. Lipid metabolite profiles and milk production for Holstein and Jersey cows fed rumen-protected choline during the periparturient period. J. Dairy Sci. 89:188-200. https://doi.org/10.3168/jds .S0022-0302(06)72083-5.

Jorritsma, R., H. Jorritsma, Y. H. Schukken, P. C. Bartlett, T. Wensing, and G. H. Wentink. 2001. Prevalence and indicators of postpartum fatty infiltration of the liver in nine commercial dairy herds in the Netherlands. Livest. Prod. Sci. 68:53-60. https://doi .org/10.1016/S0301-6226(00)00208-6.

Jorritsma, R. H. Jorritsma, Y. H. Schukken, and G. H. Wentink. 2000. Relationships between fatty liver and fertility and some periparturient diseases in commercial Dutch dairy herds. Theriogenology 54:1065-1074. https://doi.org/10.1016/S0093-691X(00)00415-5.

Katoh, N. 2002. Relevance of apolipoproteins in the development of fatty liver and fatty liver-related peripartum diseases in dairy cows. J. Vet. Med. Sci. 64:293-307. https://doi.org/10.1292/jvms .64 .293 .

Kvidera, S. K., M. J. Dickson, M. Abuajamieh, D. B. Snider, M. V. S. Fernandez, J. S. Johnson, A. F. Keating, P. J. Gorden, H. B. Green, K. M. Schoenberg, and L. H. Baumgard. 2017. Intentionally induced intestinal barrier dysfunction causes inflammation, affects metabolism, and reduces productivity in lactating Holstein cows. J. Dairy Sci. 100:4113-4127. https://doi.org/10.3168/jds .2016-12349.

Lima, F. S., M. F. Sá Filho, L. F. Greco, and J. E. P. Santos. 2012. Effects of feeding rumen-protected choline on incidence of diseases and reproduction of dairy cows. Vet. J. 193:140-145. https://doi .org/10.1016/j.tvjl.2011.09.019.

Mallard, B. A., J. C. Dekkers, M. J. Ireland, K. E. Leslie, S. Sharif, C. Lacey Vankampen, L. Wagter, and B. N. Wilkie. 1998. Alteration in immune responsiveness during the peripartum period and its ramification on dairy cow and calf health. J. Dairy Sci. 81:585595. https://doi.org/10.3168/jds.S0022-0302(98)75612-7.

McArt, J. A. A., D. V. Nydam, P. A. Ospina, and G. R. Oetzel. 2011. A field trial on the effect of propylene glycol on milk yield and resolution of ketosis in fresh cows diagnosed with subclinical ketosis. J. Dairy Sci. 94:6011-6020. https://doi.org/10.3168/jds.2011 $-4463$.

Mohsen, M. K., H. M. A. Gaafar, M. M. Khalafalla, A. A. Shitta, and A. M. Yousif. 2011. Effect of rumen protected choline supplementation on digestibility, rumen activity and milk yield in lactating Friesian cows. Slovak J. Anim. Sci. 44:13-20.

NRC. 2001. Nutrient Requirements of Dairy Cattle. 7th rev. ed. Natl. Acad. Press, Washington, DC.

Otto, K. L., J. D. Ferguson, D. G. Fox, and C. J. Sniffen. 1991. Relationship between body condition score and composition of ninth to eleventh rib tissue in Holstein dairy cows. J. Dairy Sci. 74:852-859. https://doi.org/10.3168/jds.S0022-0302(91)78234-9.

Piepenbrink, M. S., and T. R. Overton. 2003. Liver metabolism and production of cows fed increasing amounts of rumen-protected choline during the periparturient period. J. Dairy Sci. 86:17221733. https://doi.org/10.3168/jds.S0022-0302(03)73758-8.

Ramírez de Molina, A., M. Báñez-Coronel, R. Gutiérrez, A. Rodríguez-González, D. Olmeda, D. Megías, and J. C. Lacal. 2004. Choline kinase activation is a critical requirement for the proliferation of primary human mammary epithelial cells and breast tumor progression. Cancer Res. 64:6732-6739. https://doi.org/10.1158/0008 -5472.CAN-04-0489.

Reid, I. M. 1980. Incidence and severity of fatty liver in dairy cows. Vet. Rec. 107:281-284. https://doi.org/10.1136/vr.107.12.281.

Reid, I. M., C. J. Roberts, R. J. Treacher, and L. A. Williams. 1986. Effect of body condition at calving on tissue mobilization, development of fatty liver and blood chemistry of dairy cows. Anim. Prod. 43:7-15. https://doi.org/10.1017/S0003356100018298.

Reinhardt, T. A., J. D. Lippolis, B. J. McCluskey, J. P. Goff, and R. L. Horst. 2011. Prevalence of subclinical hypocalcemia in dairy herds. Vet. J. 188:122-124. https://doi.org/10.1016/j.tvjl.2010.03.025.

Rukkwamsuk, T., T. Wensing, and M. J. H. Geelen. 1998. Effect of overfeeding during the dry period on regulation of adipose tissue metabolism in dairy cows during the periparturient period. 
J. Dairy Sci. 81:2904-2911. https://doi.org/10.3168/jds.S0022 $-0302(98) 75851-5$

Santos, J. E. P., and F. S. Lima. 2009. Feeding rumen-protected choline to transition dairy cows. Pages 149 to 159 in Proc. 20th Ann. Florida Ruminant Nutr. Symp. Univ. Florida, Gainesville.

Sheldon, I. M., G. S. Lewis, S. LeBlanc, and R. O. Gilbert. 2006. Defining postpartum uterine disease in cattle. Theriogenology 65:1516-1530. https://doi.org/10.1016/j.theriogenology.2005.08 .021 .

Stockdale, C. R. 2001. Body condition at calving and the performance of dairy cows in early lactation under Australian conditions: A review. Aust. J. Exp. Agric. 41:823-839. https://doi.org/10.1071/ EA01023.

Sun, F., Y. Cao, C. Cai, S. Li, C. Yu, and J. Yao. 2016. Regulation of nutritional metabolism in transition dairy cows: Energy homeostasis and health in response to post-ruminal choline and methionine. PLoS One 11:e0160659. https://doi.org/10.1371/journal.pone .0160659 .

Takahashi, Y., T. Mizunuma, and Y. Kishino. 1982. Ultracytochemical studies on fat absorption by choline-deficient rats. Acta Histochem. Cytochem. 15:90-101. https://doi.org/10.1267/ahc.15.90.

Zahra, L. C., T. F. Duffield, K. E. Leslie, T. R. Overton, D. Putnam, and S. J. LeBlanc. 2006. Effect of rumen-protected choline and monensin on milk production and metabolism of peri-parturient dairy cows. J. Dairy Sci. 89:4808-4818. https://doi.org/10.3168/ jds.S0022-0302(06)72530-9.

Zenobi, M. G., R. Gardinal, J. E. Zuniga, A. L. G. Dias, C. D. Nelson, J. P. Driver, B. A. Barton, J. E. P. Santos, and C. R. Staples. 2018a. Effects of supplementation with ruminally protected choline on performance of multiparous Holstein cows did not depend upon prepartum caloric intake. J. Dairy Sci. 101:1088-1110. https: //doi.org/10.3168/jds.2017-13327.

Zenobi, M. G., R. Gardinal, J. E. Zuniga, L. K. Mamedova, B. J. Bradford, J. P. Driver, B. A. Barton, J. E. P. Santos, C. D. Nelson, and C. R. Staples. 2020. Effect of prepartum energy intake and supplementation with ruminally-protected choline on innate and adaptive immunity of multiparous Holstein cows. J. Dairy Sci 103:2200-2216. https://doi.org/10.3168/jds.2019-17378.

Zenobi, M. G., T. L. Scheffler, J. E. Zuniga, M. B. Poindexter, S. R. Campagna, H. F. Castro Gonzalez, A. T. Farmer, B. A. Barton, J. E. P. Santos, and C. R. Staples. 2018b. Feeding increasing amounts of ruminally protected choline decreased fatty liver in nonlactating, pregnant Holstein cows in negative energy status. J. Dairy Sci. 101:5902-5923. https://doi.org/10.3168/jds.2017-13973.

Zom, R. L., J. Van Baal, R. M. A. Goselink, M. J. de Veth, and A. M. van Vuuren. 2011. Effect of rumen-protected choline on performance, blood metabolites, and hepatic triacylglycerols of periparturient dairy cattle. J. Dairy Sci. 94:4016-4027. https://doi.org/10 $.3168 /$ jds.2011-4233.

\section{ORCIDS}

C. R. Staples $\odot$ https://orcid.org/0000-0002-0237-946X

J. E. P. Santos ๑ https://orcid.org/0000-0003-3403-1465 